\title{
PEMANFAATAN INTERNET MARKETING UNTUK MEMPERSIAPKAN MASYARAKAT KREATIF DAN BERJIWA WIRAUSAHA MANDIRI DI LINGKUNGAN WARGA PKK
}

\author{
Irwan Setiawan $^{1}$, Fitri Diani ${ }^{1}$ \\ ${ }^{1}$ Jurusan Teknik Komputer dan Informatika, Politeknik Negeri Bandung \\ Email: irwan@jtk.polban.ac.id, fitri@jtk.polban.ac.id
}

\begin{abstract}
Abstrak
Pelatihan Pemanfaatan Internet Marketing merupakan kegiatan Pengabdian Masyarakat Politeknik Negeri Bandung bekerjasama dengan PKK Kelurahan Sarijadi dan Ciwaruga yang dilaksanakan dalam 4 bulan. Kegiatan ini dapat menjadi salah satu kegiatan yang menunjang program kerja PKK pada mitra-mitra pengabdian dalam membantu menciptakan wanita-wanita yang memiliki jiwa kewirausahaan, kreatif dan mampu untuk menjadi wanita mandiri secara finasial.

Metode pelatihan dilakukan dengan menggunakan metoda ruang kelas dan experimental. Materi pelatihan yang diberikan mengenai Internet Marketing, “Enterpreneurship", Facebook Marketing, serta memberikan kesempatan peserta untuk mempraktikan secara langsung penggunaan teknologi serta tools yang dapat mendukung minatnya dalam melakukan bisnis online.

Berdasarkan evaluasi, kesimpulan yang diperoleh dari kegiatan ini adalah : (1) Terdapat kesenjangan yang cukup tinggi antara pengetahuan masyarakat yang dalam hal ini direpresentasikan oleh peserta kegiatan dengan kemajuan teknologi saat ini; (2) Lebih dari $70 \%$ peserta kegiatan telah berhasil mengimplementasikan ilmu yang didapat selama kegiatan pada bisnis masing-masing peserta.
\end{abstract}

Kata kunci: Internet marketing, entrepreneurship, bisnis online, wirausaha, PKK

\section{PENDAHULUAN}

Dalam organisasi kemasyarakatan, $\mathrm{Ru}-$ kun Warga merupakan organisasi masyarakat yang diakui dan dibina oleh pemerintah untuk memelihara dan melestarikan nilai-nilai kehidupan masyarakat Indonesia yang berdasarkan kegotongroyongan dan kekeluargaan serta untuk membantu meningkatkan kelan- caran tugas pemerintahan, pembangunan, dan kemasyarakatan di desa dan kelurahan. Dalam pelaksanaannya, setiap RW mempunyai unit yang bernama Pembinaan Kesejahteraan Keluarga, disingkat PKK, adalah organisasi kemasyarakatan yang memberdayakan wanita untuk turut berpartisipasi dalam pembangunan Indonesia. 
DIFUSI

Volume 2, No.2 Juli 2019

Melihat peran pentingnya PKK yang dalam hal ini penggeraknya adalah para wanita yang umumnya adalah Ibu $\mathrm{Ru}-$ mah Tangga (IRT), maka perlu adanya upaya untuk memberikan "edukasi" agar peran dan tugas dari PKK itu sendiri dapat lebih optimal. Fenomena IRT saat ini masih didominasi dengan keadaan yang "sangat terbatas". Mereka tidak cukup memiliki bekal untuk dapat memerankan fungsinya ditengah masyarakat padahal disatu sisi begitu sangat diharapkan perannya sebagai penggerak perekonomian dikeluarga dan masyarakat.

Kegiatan ini dilatarbelakangi kondisi kemajuan teknologi saat ini sudah menjadi bagian penting dalam aktivitas masyarakat sehari - hari, maka kehadirannya menjadi peluang untuk menjadi solusi bagi para IRT yang saat ini belum mempunyai pengetahuan akan teknologi, terlebih kemudahan untuk sarana belajar saat ini sudah demikian sangat terbuka lebar. Salah satu peluang yang dapat dimanfaatkan oleh para IRT yang ingin berwirausaha adalah pemanfaatan internet untuk mendukung aktivitas kegiatan perekonomian sehingga dapat membantu perekonomian keluarga. Pada saat ini banyak ibu rumah tangga yang melakukan kegiatan bisnis konvensional, misalnya berdagang baju, sepatu, maupun barang-barang lainnya. Dengan menggunakan teknologi internet diharapkan dapat memperluas cakrawala bisnis yang dapat dilakukan oleh para ibu rumah tangga tersebut. Selain itu, kegiatan ini akan memiliki muatan kewirausahaan yang diharapkan dapat menajamkan intuisi bisnis dari para ibu rumah tangga sehingga dapat melaku- kan bisnis dengan lebih baik melalui jendela dunia Internet.

\section{Target dan Luaran}

Target yang diharapkan dari kegiatan pengabdian ini adalah :

a. Meningkatnya kreativitas dari para IRT sehingga lebih dapat mengisi waktunya dengan lebih positif

b. Menumbuhkan kesadaran dan semangat berwirausaha

c. Memberikan beberapa best-practices dari entrepreneur skala kecil maupun menengah dalam bentuk observasi dan wawancara sederhana

d. Memberikan pembekalan pada mitra sehingga dapat berwirausaha mandiri

e. Meningkatkan pengetahuan mitra mengenai pengetahuan dan kompetensi mitra untuk menggunakan teknologi internet

f. Memberikan pengetahuan akan metode-metode pemasaran berbasis Internet

Luaran yang diharapkan dari kegiatan pengabdian ini adalah:
a. Tersedianya modul pelatihan "Penggunaan Internet";
b. Tersedianya modul pelatihan "Ke- wirausahaan";
c. Tersedianya modul pelatihan "In- ternet Marketing";
d. Tersedianya alat ukur untuk menge- tahui ketercapaian kegiatan yang dilakukan.

\section{METODE}
1. Metode Pendekatan \& Prosedur Kerja


DIFUSI

Volume 2, No.2 Juli 2019

Seperti dapat dilihat pada Gambar 1, pelaksanaan kegiatan terdiri dari 3 kegiatan utama, yaitu Persiapan, Pelaksanaan, dan Akhir kegiatan.

\section{Bentuk Partisipasi Mitra}

Adanya dukungan mitra dalam kegiatan ini sangatlah diharapkan demi tercapainya target dan tujuan yang sudah disusun. Bentuk partisipasi mitra dalam kegiatan ini antara lain:

a. Hadir dalam pelatihan tepat waktu;

b. Berperan serta aktif dalam proses belajar mengajar;

c. Bersedia untuk mengikuti semua tahapan kegiatan; d. Memberikan feedback sebagai bahan evaluasi kegiatan.

\section{Gambaran Transfer Pengetahu- an kepada Mitra}

Transfer pengetahuan yang diberikan kepada mitra (Gambar 2) dilakukan melalui pelatihan dan workshop. Pelatihan yang diberikan adalah pelatihan terkait teknologi informasi, internet marketing, dan kewirausahaan. Sedangkan workshop dilakukan dengan kegiatan praktik pembuatan media penjualan onlie dan pemanfaatan media sosial.

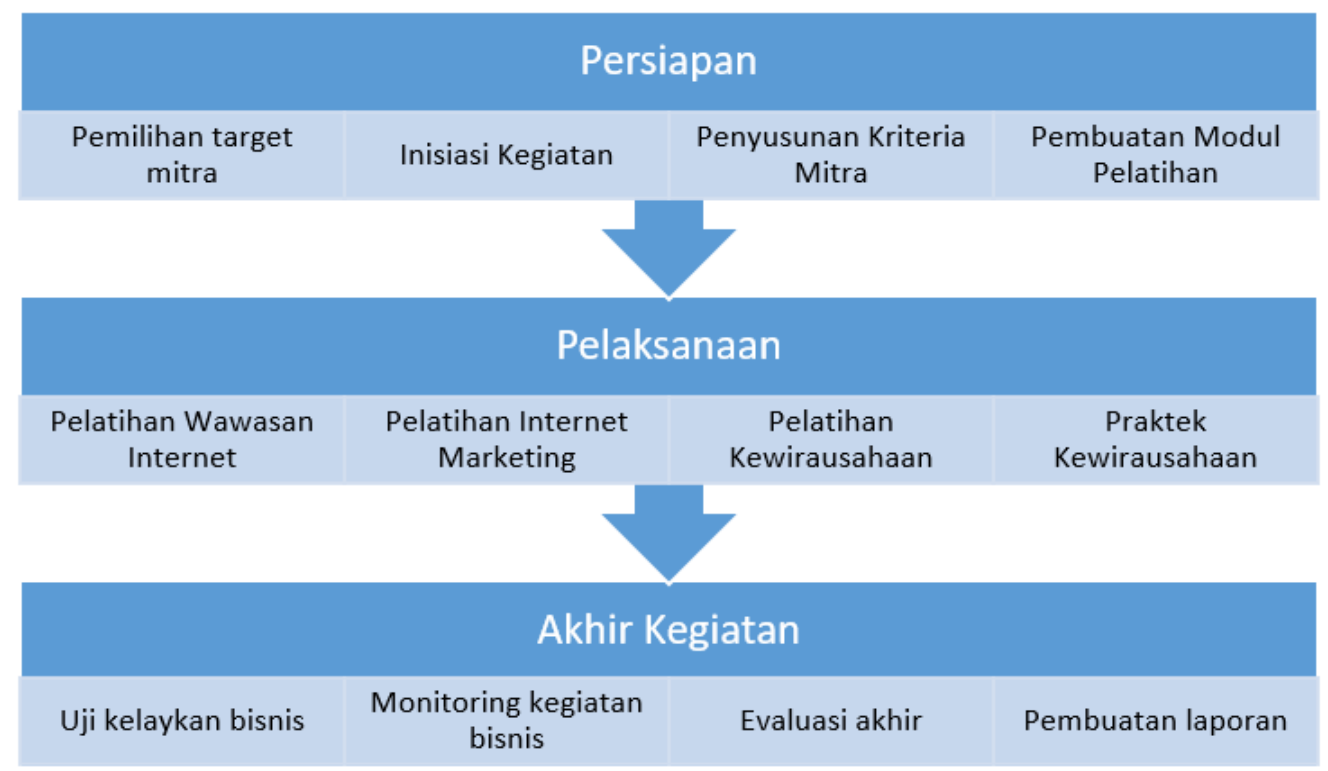

Gambar 1. Metode Pendekatan dan Prosedur Kerja 


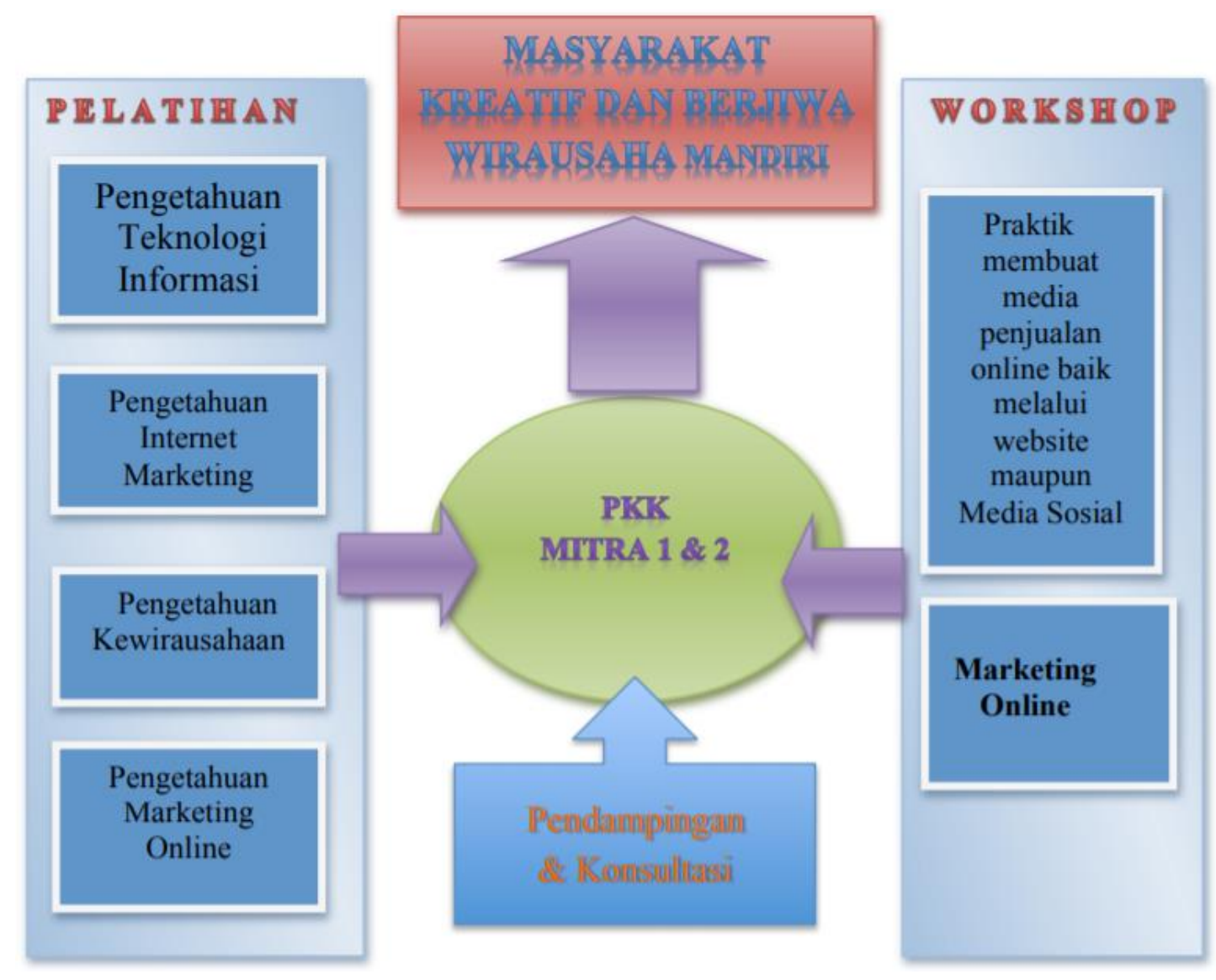

Gambar 2. Transfer Pengetahuan kepada Mitra

\section{HASIL DAN PEMBAHASAN}

Kegiatan Pengabdian Kepada Masyarakat telah berhasil dilaksanakan dengan baik dan lancar. Evaluasi mendalam terhadap permasalahan yang dihadapi mitra kegiatan pengabdian ini didapat informasi sebagai berikut :

a. Pengetahuan tentang teknologi yang masih minim, sebagian peserta merasa "gaptek";

b. Ingin dapat memaksimalkan pendapatan namun tidak memiliki keleluasaan bekerja dikarenakan harus mengurus keluarga;

c. Pemanfaatan alat telekomunikasi yg belum dioptimalkan; d. Minimnya pengetahuan tentang peluang dan keuntungan berwirausaha secara online;

e. Permasalahan modal yang tidak memadai.

\section{Profil peserta kegiatan Pengabdi- an Kepada Masyarakat}

Kegiatan pengabdian kepada masyarakat diikuti oleh 13 orang yang berasal dari 2 PKK yang terdiri dari 10 orang wanita dan 3 orang laki-laki. Profil peserta kegiatan berdasarkan usia, seperti dapat dilihat pada Gambar 3, didominasi oleh peserta dengan rentang usia 4050 tahun. 


\section{Sebaran Usia Peserta}

$\square=20 \quad 20-40 \quad 40-50$
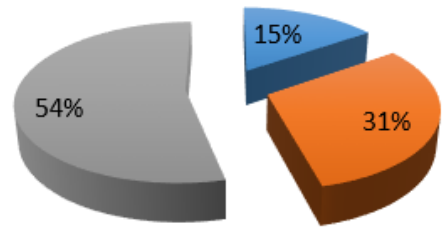

Gambar 3. Sebaran usia peserta

Profil peserta berdasarkan tingkat pendidikan (Gambar 4) terbanyak berasal dari SMA dan tidak ada yang memiliki tingkat pendidikan sarjana.

\section{Tingkat Pendidikan Peserta}

口SD-SMP $\square$ SMA $\square$ Diploma $\square$ Sarjana

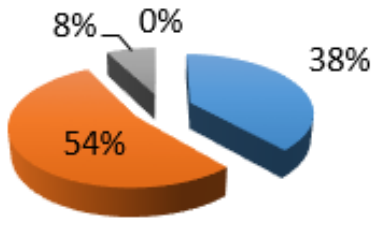

Gambar 4. Tingkat pendidikan peserta

Profil profesi peserta (Gambar 5) didominasi oleh ibu rumah tangga (IRT) sebanyak $69 \%$ dan terdapat peserta yang tidak bekerja sebanyak $15 \%$.

\section{Sebaran Profesi}

घIRT $\quad$ Freelancer $\quad$ Honorer $\square$ Tidak Bekerja

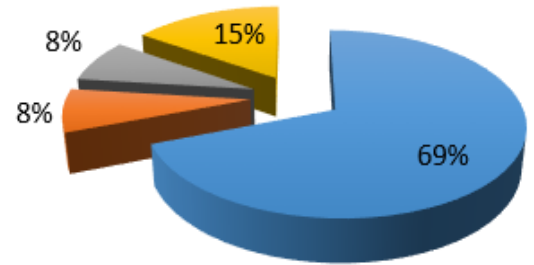

Gambar 5. Sebaran profesi peserta
Profil intensitas menggunakan teknologi peserta kegiatan (Gambar 6) didominasi oleh peserta yang biasa menggunakan teknologi dan berinteraksi dengan gadget.

\section{Intensitas Menggunakan Teknologi}

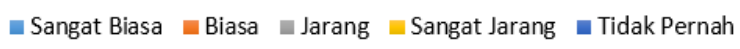

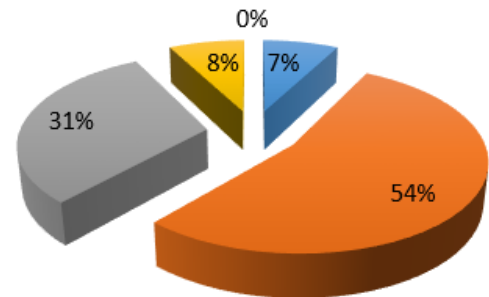

Gambar 6. Intensitas menggunakan teknologi

\section{Analisis Pengetahuan Awal}

Analisis mengenai gambaran pengetahuan awal peserta kegiatan Pengabdian Kepada Masyarakat ini diantaranya:

a. Dari sisi kepemilikian teknologi berupa telepon cerdas, $100 \%$ peserta memiliki telepon cerdas. Namun penggunaan telepon tersebut belum dimaksimalkan. Rata-rata peserta menggunakan teleponnya hanya untuk melakukan panggilan, SMS, menggunakan media social dan memanfaatkan kamera untuk melakukan foto-foto. Media sosial yang digunakan pada umumnya hanya media social Facebook saja. Peserta belum mengenal media sosial lain seperti Twitter, Path, Instagram, LinkedIn dll. Penggunaan Facebook pun hanya sebatas memiliki akun untuk eksistensi profile saja, sebanyak 10 orang memiliki akun 
Facebook dan sebanyak 3 orang tidak memiliki akun Facebook;

b. Akun Facebook yang dimiliki oleh para peserta rata-rata merupakan akun Facebook yang tidak aktif. Peserta memiliki akun hanya karena di pasangkan oleh orang lain pada saat membeli telepon cerdas atau dipasangkan oleh anggota keluarganya, sehingga peserta sendiri tidak paham peruntukan menggunakan Facebook;

c. Seluruh peserta mengetahui tentang Bisnis Online, namun belum memiliki gambaran yang jelas mengenai bisnis online itu seperti apa. Mereka pada umumnya mengenal Bisnis Online itu merupakan bisnis yang membutuhkan modal yang cukup besar untuk investasi teknologinya seperti untuk membuat situs web, menyediakan perangkat pendukung teknologi, dan di sisi lain para peserta juga memiliki kesulitan dalam mendapatkan modal awal. Kesulitan dalam mendapatkan modal awal pun merupakan ketakutan tersendiri bagi hampir seluruh peserta sehingga pada akhirnya peserta hanya bisa bermimpi ingin berbisnis namun tak merasa mungkin untuk mewujudkan mimpi-mimpi tersebut;

d. Peserta pada umumnya belum mengetahui tentang pengetahuan kewirausahaan. Dalam pemahaman peserta, berwirausaha artinya memiliki pabrik, memiliki toko, ataupun memiliki kantor yang memerlukan modal cukup besar;

e. Dari sisi minat berwirausaha dari peserta, hampir seluruh peserta memiliki minat yang tinggi untuk berwirausaha. Namun, belum mengerti harus memulai dari mana, dari apa, dan bagaimana memulai untuk berwirausaha.

\section{Analisis Pasca Kegiatan Pelatih- an}

Questioner pasca pelaksanaan kegiatan Pengabdian Kepada Masyarakat ini dibuat sebanyak 2 (dua) bagian, yaitu :

a. Untuk menilai pelaksanaan kegiatan secara umum;

b. Untuk menilai konten/materi yang diberikan.

Hasil analisis pelaksanaan kegiatan secara umum diantaranya:

a. Sebanyak $92 \%$ peserta menilai kegiatan terlaksanakan dengan sangat baik dan sebanyak $8 \%$ menilai kegiatan terlaksana dengan baik.

b. Sebanyak $70 \%$ peserta menilai materi yang diberikan sangat baik dan sebanyak $30 \%$ menilai materi yang diberikan baik.

c. Sebanyak $77 \%$ peserta menilai pemateri menyampaikan materi dengan sangat baik dan sebanyak $23 \%$ menilai pemateri menyampaikan materi dengan baik.

d. Sebanyak $70 \%$ peserta menilai fasilitas yang diberikan sangat baik dan sebanyak $30 \%$ menilai fasilitas yang diberikan baik.

e. Sebanyak $93 \%$ peserta menilai sangat setuju bahwa kegiatan ini meningkatkan wawasan dan sebanyak $7 \%$ peserta menilai setuju bahwa kegiatan ini meningkatkan wawasan.

f. Sebanyak $85 \%$ peserta menilai sangat setuju bahwa kegiatan ini bermanfaat dan sebanyak 15\% menilai setuju bahwa kegiatan ini bermanfaat. 
DIFUSI

Volume 2, No.2 Juli 2019

g. Sebanyak $70 \%$ peserta menilai sangat setuju bahwa ilmu yang didapat dapat diimplementasikan dan sebanyak 30\% menilai setuju bahwa ilmu yang didapat dapat diimplementasikan.

h. Sebanyak $77 \%$ peserta menilai sangat setuju untuk kegiatan ini dilaksanakan lagi di waktu mendatang dan sebanyak $23 \%$ menilai setuju untuk kegiatan ini dilaksanakan lagi di waktu mendatang.

i. Kesan, pesan, dan saran dari peserta yang disampaikan secara deskriptif, dapat dikelompokkan ke dalam poin-poin di bawah ini :

1) Kegiatan ini sangat baik, sangat bagus, dan sangat memberikan inspirasi sekaligus memberikan berbagai inspirasi bagi peserta.

2) Kegiatan ini sangat bermanfaat sehingga di sarankan agar dapat dilaksanakan kembali di waktu mendatang.

3) Kegiatan ini sangat membantu membuka wawasan mengenai peluang-peluang untuk memiliki hidup yang lebih baik dengan melakukan bisnis secara online.

4) Kegiatan ini dapat menjadi ajang silaturahmi dari lingkungan akademik ke masyarakat umum, sehingga sangat membantu untuk menghilangkan batas-batas antara lingkungan akademik dengan masyarakat umum yang tidak sempat mengecap pendidikan tinggi.

\section{Aktifitas Kegiatan Pengabdian}

Beberapa dokumentasi kegiatan pengabdian yang dilakukan:
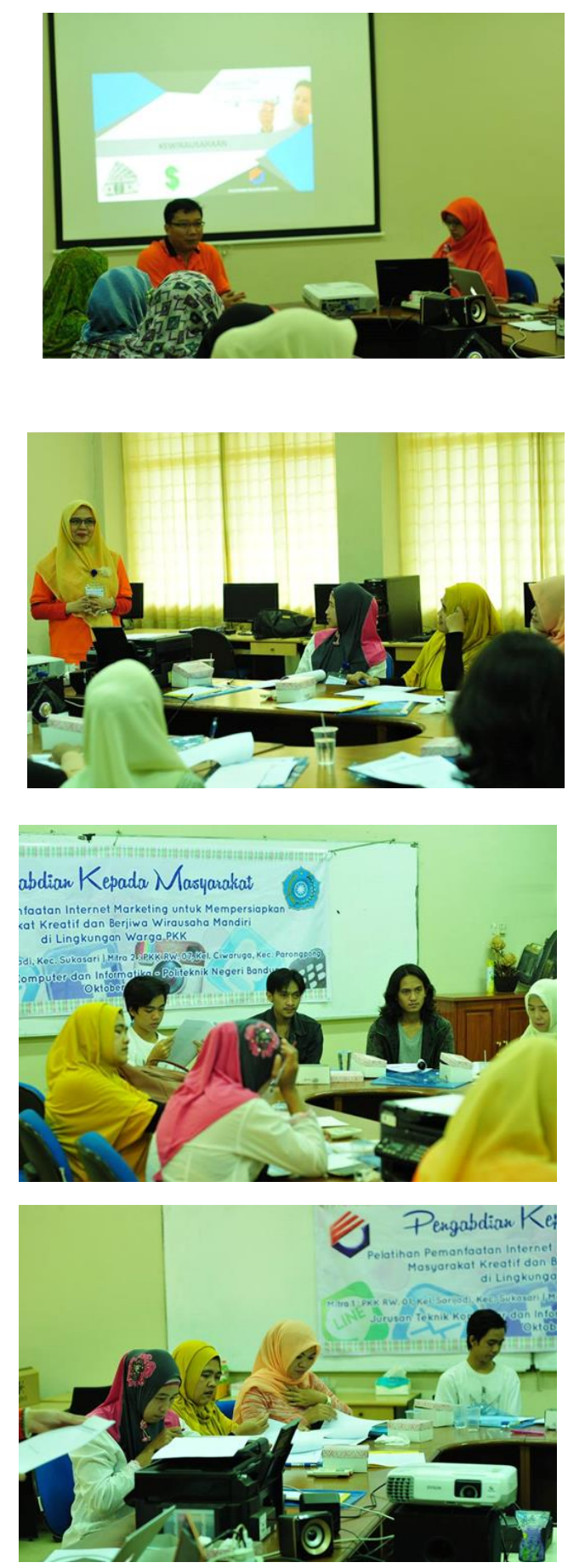

Gambar 7. Dokumentasi kegiatan pengabdian 
DIFUSI

Volume 2, No.2 Juli 2019

\section{Aktifitas Monitoring Kegiatan Pengabdian}

Beberapa dokumentasi monitoring kegiatan pengabdian yang dilakukan:

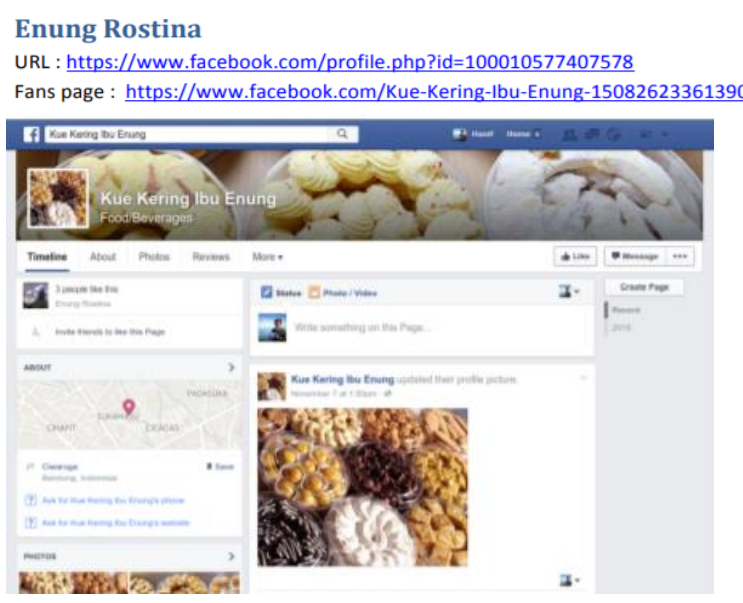

Chaerul Abdillah

URL Profil: https://www.facebook.com/abdillahcrl URL Fans Page: : https://www.facebook.com/subhawaams

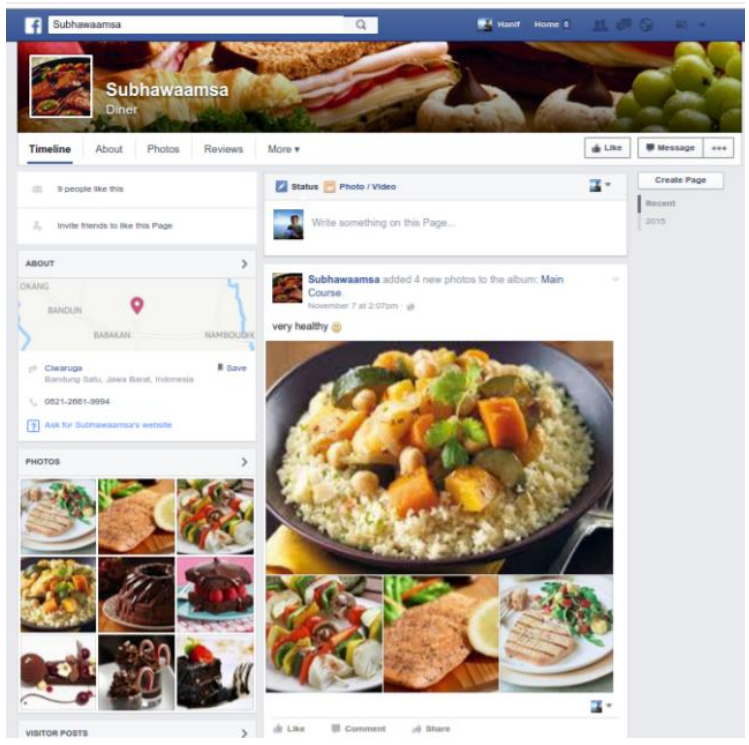

Dewi Wati

URL PROFILE : https://www.facebook.com/profile.php?id=1000104676994 URL FANS PAGE : https://www.facebook.com/sambaberbandung

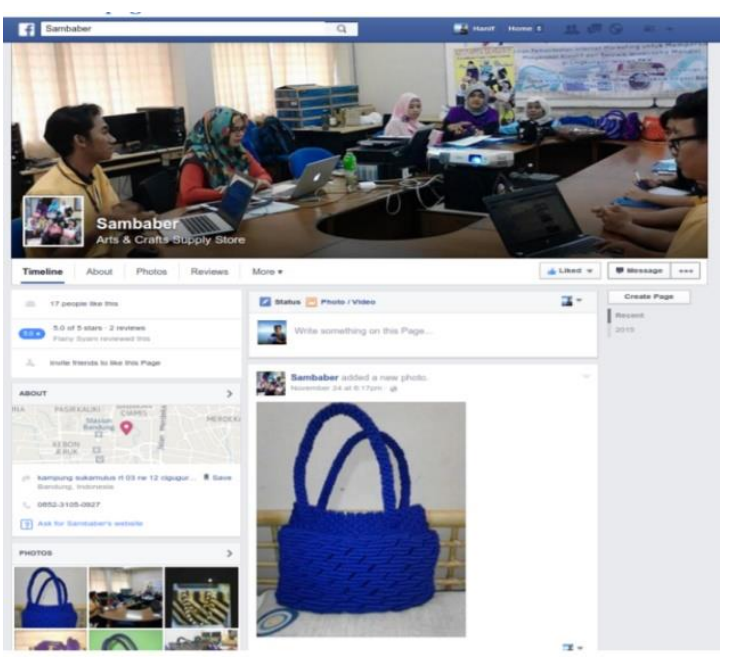

Avriyanti Soraya

URL PROFILE : https://www.facebook.com/aviriyanti.soraya

URL FANS PAGE : https://www.facebook.com/aviriyantishop/

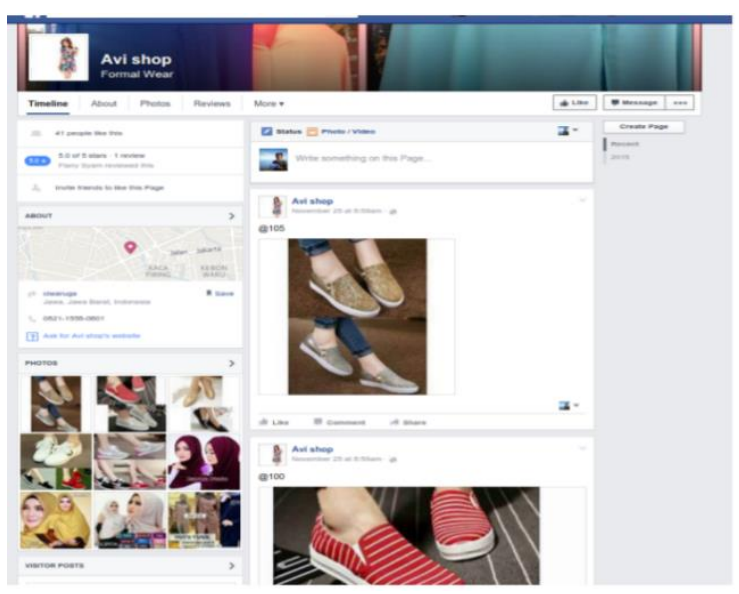

Gambar 8. Dokumentasi monitoring kegiatan pengabdian

\section{KESIMPULAN}

Kesimpulan yang dapat diambil dari kegiatan pengabdian ini adalah:

1. Sebagian masyarakat sekitar Politeknik Negeri Bandung yang direpresentasikan oleh ibu-ibu PKK dan pemuda Karang Taruna dari kelompok Mitra kegiatan ini, merupakan masyarakat yang memang 
perlu di bantu untuk meningkatkan pengetahuan mereka akan teknologi. Perkembangan teknologi yang tak terbendung menyebabkan terdapat kesenjangan yang cukup jauh antara kondisi pengetahuan masyarakat terhadap pengetahuan mereka mengenai teknologi. Pengetahuan yang di maksud mencakup: mengetahui tentang teknologi tersebut, dapat menggunakan teknologi, hingga dapat memanfaatkan teknologi untuk kehidupan yang jauh lebih baik.

2. Kegiatan ini dilaksanakan sesuai dengan metode pengajaran, metode tutorial serta metode pendampingan yang cukup intens dengan memanfaatkan teknologi Internet, memanfaatkan media sosial Facebook dan kegiatan ini dapat dikatakan berhasil dilaksanakan dengan baik dan memberikan dampak yang cukup signifikan terhadap kondisi peserta pelatihan. Sebanyak 10 orang dari 13 orang peserta sudah mulai melakukan kegiatan bisnis dengan memanfaatkan Facebook pribadi maupun Facebook FanPage sampai jangka waktu pendampingan. Angka tersebut menunjukan lebih dari $70 \%$ dari peserta berhasil mengimplementasikan ilmu dan penga laman yang didapat dari pelatihan ini. Kegiatan sharing atau membagikan pengetahuan dari lingkungan akademisi ke masyarakat secara langsung, merupakan kegiatan yang sangat baik dan perlu dilakukan secara terus menerus dan berkesinambungan.

\section{REFERENSI}

[1] A.R, H., 2012. Program Kerja PKK. [Online]

Available at: http: //ariprahmanhakim1206.blogspot.com [Diakses 2012].

[2] Anon., 2012. Jurnal Manajemen Fakultas Ekonomi Universitas Jambi. Digital Jambi, 1(ISSN : 2302- 4682).

[3] F, R., 2010. Silabus dan RPP Kewirausahaan. [Online] Available at: http:// staff.uny.ac.id/sites/ [Diakses 2014].

[4] Harini, C. \& Praptono, S., 2017. Pengembangan Pemasaran Kewirausahaan dalam Upaya Meningkatkan Kinerja Perekonomian Unit Usaha Mikro Kecil Menengah di Kota Semarang. Semarang, SNATIF.

[5] Nawir, t.thn. Pemberdayaan Kesejahteraan Keluarga. [Online] Available at: https: //www.kemsos.go.id/ [Diakses April 2014]. 